\title{
Perbedaan pH Saliva Setelah Mengonsumsi Susu Sapi Murni dan Susu Sapi Bubuk
}

\author{
${ }^{1}$ Iriana T. Seralurin \\ ${ }^{2}$ Vonny N. S. Wowor \\ ${ }^{3}$ Shane H. R. Ticoalu
}

\author{
${ }^{1}$ Program Studi Pendidikan Dokter Gigi Fakultas Kedokteran \\ ${ }^{2}$ Bagian Ilmu Kesehatan Gigi Mulut Program Studi Pendidikan Dokter Gigi \\ ${ }^{3}$ Bagian Anatomi-Histologi Fakultas Kedokteran \\ Universitas Sam Ratulangi Manado \\ Email: seralurinyana@gmail.com
}

\begin{abstract}
Saliva is a complex oral fluid consisting of a mixture of secretion of the major and minor salivary glands in the oral mucosa with a normal $\mathrm{pH}$ of 5.6-7.0. There are several factors that can cause changes in the salivary $\mathrm{pH}$, as follows: average saliva flow rate, oral microorganisms, salivary buffer capacity, and food and beverages oftenly consumed inter alia milk. Milk contains a lot of nutrients such as carbohydrates, proteins, minerals, and vitamins. This study was aimed to determine the difference of salivary $\mathrm{pH}$ after consuming pure cow milk and powdered cow milk, and to obtain the salivary $\mathrm{pH}$ after consuming pure cow milk or powdered cow milk. This was an experimental study using pretest-posttest study design. There were 38 respondents. Each respondent consumed pure cow milk or powdered cow milk. Decreased salivary $\mathrm{pH}$ was more dominant in respondents who consumed powdered cow milk. The Mann-Whitney test showed that there was a difference of salivary $\mathrm{pH}$ between after consuming pure cow milk and powdered cow milk $(P=0.000)$. Conclusion: There was a significant difference in salivary $\mathrm{pH}$ between after consuming pure cow milk and powdered cow milk. Salivary pH showed bigger dicrease after consuming powdered cow milk than consuming pure cow milk.
\end{abstract}

Keywords: salivary pH, pure cow milk, powdered cow milk

\begin{abstract}
Abstrak: Saliva merupakan cairan rongga mulut yang kompleks, terdiri atas campuran sekresi kelenjar saliva mayor dan minor yang terdapat dalam mukosa mulut dengan $\mathrm{pH}$ saliva berkisar 5,6-7,0. Beberapa faktor yang menyebabkan terjadinya perubahan pada $\mathrm{pH}$ saliva antara lain rerata kecepatan aliran saliva, mikroorganisme rongga mulut, kapasitas bufer saliva, serta makanan dan minuman yang sering di konsumsi; salah satunya ialah susu. Susu mengandung banyak zat-zat makanan seperti karbohidrat, protein, mineral, dan vitamin. Penelitian ini bertujuan untuk mengetahui perbedaan $\mathrm{pH}$ saliva setelah mengonsumsi susu sapi murni dan susu sapi bubuk, dan untuk mengetahui $\mathrm{pH}$ saliva setelah mengonsumsi susu sapi murni dan susu sapi bubuk. Jenis penelitian ialah eksperimental dengan pretest-posttest study design. Terdapat total 38 responden penelitian. Setiap responden mengonsumsi susu sapi murni atau susu sapi bubuk sebanyak 250ml. Pengukuran $\mathrm{pH}$ saliva dilakukan pada menit ke-5 setelah mengonsumsi susu sapi murni atau susu sapi bubuk. Uji Mann-Whitney menunjukkan terdapat perbedaan $\mathrm{pH}$ saliva setelah mengonsumsi susu sapi murni dan susu sapi bubuk $(P=0,000)$. Penurunan $\mathrm{pH}$ saliva terbanyak terdapat pada responden yang meminum susu sapi bubuk. Simpulan: Terdapat perbedaan bermakna antara $\mathrm{pH}$ saliva setelah mengonsumsi susu sapi murni dan susu sapi bubuk. Penurunan $\mathrm{pH}$ saliva setelah mengonsumsi susu sapi bubuk lebih besar dibandingkan setelah mengonsumsi susu sapi murni.
\end{abstract}

Kata kunci: pH saliva, susu sapi murni, susu sapi bubuk 
Kesehatan gigi dan mulut memiliki peran penting dalam fungsi bicara, pengunyahan, dan rasa percaya diri; oleh karena itu kebersihan gigi dan mulut yang harus dijaga sebaik-baiknya. Efek dari kebersihan gigi dan mulut yang tidak dijaga adalah karies gigi, penyakit periodontal dan sebagainya.

Hasil RISKESDAS tahun 2013 menyebutkan bahwa prevalensi nasional masalah kesehatan gigi dan mulut sebesar 25,9\%, dimana prevalensi Sulawesi Utara sebesar $31,6 \%{ }^{1}$ Penyakit gigi dan mulut yang terbanyak diderita masyarakat ialah karies gigi kemudian diikuti oleh penyakit periodontal di urutan kedua. Karies merupakan kerusakan jaringan keras gigi yang disebabkan oleh asam yang terdapat dalam karbohidrat melalui perantara mikroorganisme di dalam saliva. ${ }^{2,3}$

Saliva merupakan cairan rongga mulut yang kompleks, terdiri atas campuran sekresi dari kelenjar saliva mayor dan minor di mukosa mulut. ${ }^{2}$ Saliva memiliki beberapa fungsi, antara lain melindungi jaringan di dalam rongga mulut dengan cara pembersihan secara mekanis untuk mengurangi akumulasi plak pada permukaan gigi; lubrikasi elemen gigi-geligi; pengaruh penyanggah; membantu fungsi pengecapan dan pencernaan; serta membantu perbaikan jaringan. Fungsi perlindungan saliva sangat dipengaruhi oleh perubahan yang berhubungan dengan komposisi maupun viskositas, sususan ion serta protein saliva, dan $\mathrm{pH}$ saliva. ${ }^{3}$

Potential of hydrogen saliva $(\mathrm{pH}$ saliva) merupakan derajat keasaman saliva yang dalam keadaan normal berkisar antara 5,6-7,0 dengan rerata $\mathrm{pH}$ 6,7. Beberapa faktor yang menyebabkan terjadinya perubahan pada $\mathrm{pH}$ saliva antara lain rerata kecepatan aliran saliva, mikroorganisme dalam rong-ga mulut, kapasitas bufer saliva, serta makanan dan minuman yang sering dikonsumsi. ${ }^{4}$

Salah satu minuman yang memengaruhi $\mathrm{pH}$ saliva ialah susu. Susu merupakan bahan minuman yang mengandung hampir semua zat-zat makanan seperti karbohidrat, protein, mineral, dan vitamin. ${ }^{5}$ Susu juga merupakan nutrisi yang ideal dalam masa pertumbuhan dan menjadi nutrisi yang sangat digemari, mulai dari anak, remaja, dan bahkan dewasa. Data konsumsi susu yang dibuat di pabrik yaitu susu kental manis, susu bubuk, dan susu bubuk bayi. Rerata konsumsi susu cair pabrik pada tahun 2002-2013 sebesar 0,07 kg/kapita/ tahun. Menurut survei nasional (Susenas) pada tahun 2014, konsumsi susu meningkat sebesar 2,45\% atau menjadi $0,1197 \mathrm{~kg} /$ kapita/tahun. ${ }^{6}$

Penelitian yang dilakukan oleh Masih et al. ${ }^{5}$ menyimpulkan bahwa terjadi penurunan $\mathrm{pH}$ saliva setelah mengonsumsi plain milk, sweetened milk, dan susu formula. Penelitian mengenai perubahan $\mathrm{pH}$ saliva setelah mengonsumsi susu juga dilakukan oleh Khokadadadi et al. ${ }^{7}$ yang membandingkan pengaruh susu beraneka rasa terhadap $\mathrm{pH}$ saliva. Hasil penelitian tersebut menyatakan bahwa terjadi penurunan $\mathrm{pH}$ saliva setelah mengonsumsi susu beraneka rasa, tetapi $\mathrm{pH}$ saliva kembali normal setelah 30 menit.

Penelitian ini bertujuan untuk mengetahui perbedaan $\mathrm{pH}$ saliva setelah mengonsumsi susu sapi murni dan susu sapi bubuk pada mahasiswa Pendidikan Dokter Gigi Universitas Sam Ratulangi Manado.

\section{BAHAN DAN METODE PENELITIAN}

Jenis penelitian yang digunakan ialah eksperimental dengan pretest-posttest study design. Penelitian ini dilakukan terhadap mahasiswa Program Studi Pendidikan Dokter Gigi Universitas Sam Ratulangi pada bulan Agustus 2017. Populasi penelitian ialah mahasiswa Program Studi Pendidikan Dokter Gigi Universitas Sam Ratulangi Angkatan 2014-2015 yang berjumlah 38 orang.

Sebelum dilakukan pengukuran $\mathrm{pH}$ saliva awal setiap responden diinstruksikan untuk menyikat gigi terlebih dahulu yaitu sebelum pengambilan saliva awal (pretest) dan setelah mengonsumsi susu sapi murni dan susu bubuk (posttest). Penelitian ini menggunakan susu sapi murni yang diperah langsung dari sapi di Desa Pinaras dan susu 
sapi bubuk jenis Dancow sebanyak $250 \mathrm{ml}$ dengan cara diteguk dalam waktu 5 menit.

Data dianalisis menggunakan Uji Mann-Whitney untuk melihat perbedaan perubahan $\mathrm{pH}$ saliva sebelum dan setelah mengonsumsi susu sapi murni dan susu sapi bubuk.

\section{HASIL PENELITIAN}

Terdapat total 38 responden yang terdiri dari 7 orang laki-laki $(18,4 \%)$ dan 31 orang perempuan (81,6\%) (Tabel 1). Responden terbanyak berusia 20 tahun $(44,7 \%)$ dan paling sedikit berusia 22 tahun (2,6\%) (Tabel 2).

Tabel 1. Karakteristik responden berdasarkan jenis kelamin

\begin{tabular}{ccc}
\hline Jenis kelamin & $\mathbf{n}$ & $\mathbf{\%}$ \\
\hline Laki-laki & 7 & 18,4 \\
Perempuan & 31 & 81,6 \\
Total & 38 & 100 \\
\hline
\end{tabular}

Tabel 2. Karakteristik responden berdasarkan usia

\begin{tabular}{ccc}
\hline Usia (tahun) & $\mathbf{n}$ & $\mathbf{\%}$ \\
\hline 19 & 11 & 28,9 \\
20 & 17 & 44,7 \\
21 & 9 & 23,7 \\
22 & 1 & 2,6 \\
Total & 38 & 100 \\
\hline
\end{tabular}

Tabel 3 memperlihatkan bahwa sebelum minum susu murni, persentase tertinggi responden memiliki $\mathrm{pH}$ normal (52,6\%), sedangkan setelah minum susu murni persentase tertinggi responden memiliki pH asam (68,4\%).

Tabel 3. Distribusi frekuensi $\mathrm{pH}$ saliva pada responden yang mengonsumsi susu sapi murni

\begin{tabular}{ccccc}
\hline Kategori & \multicolumn{3}{c}{ Konsumsi susu murni } \\
\hline & \multicolumn{2}{c}{ Sebelum } & \multicolumn{2}{c}{ Sesudah } \\
& $\mathrm{n}$ & $\%$ & $\mathrm{n}$ & $\%$ \\
Normal & 9 & 47,3 & 6 & 31,5 \\
Asam & 6 & 31,5 & 13 & 68,4 \\
Basa & 4 & 21,05 & 0 & 0 \\
\hline
\end{tabular}

Tabel 4 menunjukkan bahwa sebelum minum susu bubuk, persentase tertinggi responden memiliki $\mathrm{pH}$ normal (52,6\%), sedangkan setelah minum susu bubuk persentase tertinggi responden memiliki $\mathrm{pH}$ asam (94,7\%).

Tabel 4. Distribusi frekuensi keadaan $\mathrm{pH}$ saliva pada responden yang mengonsumsi susu sapi bubuk

\begin{tabular}{ccccc}
\hline Kategori & \multicolumn{3}{c}{ Konsumsi susu bubuk } \\
\hline & \multicolumn{2}{c}{ Sebelum } & \multicolumn{2}{c}{ Sesudah } \\
& $\mathrm{n}$ & $\%$ & $\mathrm{n}$ & $\%$ \\
Normal & 10 & 52,6 & 1 & 5,26 \\
Asam & 7 & 36,8 & 18 & 94,7 \\
Basa & 2 & 10,5 & 0 & 0 \\
\hline
\end{tabular}

Uji Mann-Whitney terhadap perbedaan $\mathrm{pH}$ sebelum dan setelah mengonsumsi susu sapi murni dan susu sapi bubuk mendapatkan nilai $P=0,000(<0,05)$ yang menunjukkan adanya perbedaan bermakna antara nilai $\mathrm{pH}$ setelah mengonsumsi kedua jenis susu tersebut.

\section{BAHASAN}

Telah dilakukan penelitian terhadap mahasiswa Program Studi Pendidikan Dokter Gigi Universitas Sam Ratulangi. Responden yang terdiri dari mahasiswa Angkatan 2014-2015 berjumlah 38 orang yang dibagi menjadi 2 kelompok. Kelompok pertama terdiri dari 19 orang diberi perlakuan mengonsumsi susu sapi murni dan kelompok kedua yang juga terdiri dari 19 orang diberi perlakuan mengonsumsi susu sapi bubuk. Dilakukan pengukuran $\mathrm{pH}$ awal sebelum dan setelah mengonsumsi susu sapi muni dan susu sapi bubuk.

Karakteristik responden berdasarkan jenis kelamin terlihat bahwa jumlah responden terbanyak yaitu perempuan sebanyak 31 orang (81,6\%) sedangkan responden laki-laki sebanyak 7 orang (18,4\%). Responden terbanyak berusia 20 tahun sebanyak 17 orang (44,7\%), usia 19 tahun sebanyak 11 orang (28,9\%), usia 21 tahun sebanyak 9 orang $(23,7 \%)$ dan usia 22 tahun sebanyak 1 (2,6\%). 
Hasil penelitian menunjukkan bahwa sebelum mengonsumsi susu sapi murni terbanyak memiliki $\mathrm{pH}$ saliva normal yaitu sebanyak 9 responden (47,3\%), nilai $\mathrm{pH}$ saliva asam sebanyak 6 responden (31,5\%), dan nilai $\mathrm{pH}$ saliva basa yaitu sebanyak 4 responden (21,05\%). Setelah minum susu sapi murni yang terbanyak ialah dengan nilai $\mathrm{pH}$ saliva asam sebanyak 13 responden (68,4\%), nilai $\mathrm{pH}$ saliva normal sebanyak 6 responden (31,5\%), dan $\mathrm{pH}$ saliva basa tidak ada responden (0\%).

Hasil penelitian memperlihatkan bahwa $\mathrm{pH}$ saliva responden sebelum minum susu sapi bubuk terbanyak memiliki nilai $\mathrm{pH}$ saliva normal sebanyak 10 responden (52,6\%), nilai $\mathrm{pH}$ saliva asam sebanyak 7 responden (36,8\%), dan nilai $\mathrm{pH}$ saliva basa sebanyak 2 responden (10,5\%). Pada responden yang meminum susu sapi bubuk terbanyak memiliki nilai $\mathrm{pH}$ saliva asam yaitu 18 responden (94,7\%), nilai $\mathrm{pH}$ saliva normal yaitu 1 responden (5,26\%), dan nilai $\mathrm{pH}$ saliva basa yaitu tidak ada responden (0\%).

Hasil pengukuran $\mathrm{pH}$ saliva setelah mengonsumsi susu sapi murni dan susu sapi bubuk mendapatkan nilai $\mathrm{pH}$ saliva terbanyak mengalami penurunan $(P=0,000$ $<0,05)$. Penurunan $\mathrm{pH}$ saliva yang terjadi setelah mengonsumsi susu baik susu sapi murni maupun susu sapi bubuk dapat disebabkan karena kandungan karbohidrat seperti laktosa dalam susu difermentasi oleh bakteri kariogenik dan menghasilkan produk asam yang dapat menurunkan $\mathrm{pH}$ saliva. ${ }^{8}$ Mengenai rerata $\mathrm{pH}$ saliva, setelah mengonsumsi susu bubuk terjadi penurunan $\mathrm{pH}$ saliva yang lebih besar dibandingkan mengonsumsi susu sapi murni. Hal ini disebabkan dalam susu bubuk terdapat kandungan karbohidrat berupa laktosa dan juga penambahan sukrosa sehingga $\mathrm{pH}$ saliva setelah mengonsumsi susu bubuk mengalami penurunan yang lebih besar. ${ }^{8}$ Hasil penelitian ini selaras dengan penelitian oleh Kartikawati $^{9}$ yang menyatakan bahwa penurunan $\mathrm{pH}$ saliva setelah mengonsumsi susu sapi murni lebih sedikit dibandingkan susu sapi bubuk (susu formula). Penurunan $\mathrm{pH}$ dalam rongga mulut dapat menyebabkan demineralisasi elemen gigi dengan cepat namun tidak semua penurunan $\mathrm{pH}$ saliva menyebabkan demineralisasi elemen gigi. Keadaan $\mathrm{pH}$ dan kapasitas bufer saliva memengaruhi terjadinya karies gigi dalam rongga mulut. Semakin rendah $\mathrm{pH}$ saliva, maka karies gigi cenderung semakin tinggi. ${ }^{10}$

Karies merupakan kerusakan jaringan keras gigi yang disebabkan oleh asam yang terdapat dalam karbohidrat melalui peratara mikroorganisme di dalam saliva. Karies gigi adalah proses demineralisasi email gigi yang menyebabkan kerusakan enamel dan dentin. Terdapat empat faktor utama (faktor internal) yang menjadi penyebab langsung terjadinya karies, yaitu host, agen, substrat, dan waktu. ${ }^{11}$

\section{SIMPULAN}

Dari hasil penelitian ini dapat disimpulkan bahwa terdapat perbedaan bermakna antara $\mathrm{pH}$ saliva setelah mengonsumsi susu sapi murni dan susu sapi bubuk. Terdapat penurunan $\mathrm{pH}$ saliva setelah mengonsumsi susu sapi bubuk yang lebih besar dibandingkan setelah mengonsumsi susu sapi murni.

\section{SARAN}

Disarankan untuk melakukan penelitian lanjut tentang volume saliva, kecepatan saliva, dan jumlah bakteri Streptococcus mutans untuk mengetahui secara lebih akurat pengaruh konsumsi susu sapi murni dan susu sapi bubuk.

Susu sapi murni dapat dijadikan alternatif yang lebih baik untuk dikonsumsi daripada susu sapi bubuk karena mempunyai efek menurunkan $\mathrm{pH}$ lebih sedikit dibandingkan susu sapi bubuk sehingga kemungkinan menyebabkan karies lebih kecil.

\section{DAFTAR PUSTAKA}

1. RIKESDAS 2013. Badan Penelitian dan Pengembangan Kesehatan Kementrian Kesehatan RI [online]. Available from: http:/www.depkes.go.id/resoures/downl oad.

2. Kidd EAM, Bechal SJ. Dasar-dasar Karies 
Penyakit dan Penanggulangannya. Jakarta: EGG, 2013; p. 66-70.

3. Hidayani TA, Handajani J. Efek merokok terhadap status $\mathrm{pH}$ dan volume saliva pada laki - laki usia dewasa dan usia lanjut. Dentika. 2010;15(2):146-8.

4. Pradanta YE, Adhani R, Khatimah IH. Hubungan kadar $\mathrm{pH}$ dan volume saliva terhadap indeks karies masyarakat menginang Kecamatan Lokpaikat Kabupaten Tapin. Dentino. 2016;I(2): 159.

5. Masih U, Prabhakar M, Joshi J.L, Mahai P. A comperative study of acidogenic potential of milk and commonly used milk formula. International Journal of Dental Clinic. 2010;2(4):30-2.

6. Respati E, Hasanah L. Buletin Konsumsi Pangan. 2013;4(4):35-7.

7. Khodadadi E, Ghasemi N, Pouramir M, Bijani A. Total antioxidant property and $\mathrm{pH}$ change of dental plaque and saliva in 6-11 years old children after consumption of flavored milk. Caspian Journal of Dental Research. 2013;2(2):15-22.

8. De Mazer Papa AM, Tabchoury CP, Del Bel Cury AA, Tenuta LM, Arthur RA, Cury JA. Effect of milk and soy-based infant formulas on in situ demineralization of human primay enamel. Pediatr Dent. 2010;32(1):35-40.

9. Kartikawati D. Perbedaan $\mathrm{pH}$ saliva setelah minum susu sapi segar dan susu formula pada anak-anak [Skripsi thesis]. Surabaya: Fakultas Kedokteran Gigi Universitas Airlangga; 2004.

10. Rantonen P. Salivary flow and composition in healthy and disease adults [Dissertation]. Helsinki: Helsinki University Central Hospital; 2006.

11. Stephen KW, Speirs CF. Methods for collecting individual components of mixed saliva: The relevance to clinical pharmacology. BJCP.1976;3(2):315-9. 